\title{
PERLINDUNGAN HUKUM PADA HAK PATEN TERHADAP HAK CIPTA DAN KEDALA PEEGAKAN HUKUM
}

\author{
EGA YULIANI \\ 155100023, 785567895 \\ Fakultas Komputer \\ egayuliani.student@umitra.ac.id
}

\begin{abstract}
Penelitian ini bertujuan untuk mengetahui dengan ketentuan Undang-Undang No. 14 tahun 2001. Metode yang digunakan penulis dalam penelitian ini adalah metode kualitatif, yaitu menekankan proses pemahaman peneliti atas perumusan masalah untuk mengkonstruksikan gejala hukum bagaimana proses perolehan dan perlindungan atas hak paten di Indonesia berdasarkan UU Paten, perlindungan hukum bagi pemegang hak paten di Indonesia yang dikaitkan dalam kasus pembatalan hak paten milik Edijanto, Untuk mengetahui hambatan-hambatan apa saja yang ada dalam pelaksanaan perlindungan hak paten di Indonesia Jenis penelitian yang digunakan oleh penulis dalam penelitian ini adalah deskriptif analisis,Pada penelitian ini menggunakan obyek adalah perlindungan hak kekayaan intelektual paten di Indonesia.Teknik pengumpulan data penelitian ini adalah studi kepustakaan dan studi lapangan. Berdasarkan pada hasil analisis dan pembahasan pada bagian sebelumnya maka dapat ditarik kesimpulan sebagai berikut: Proses perolehan dan perlindungan atas hak paten di Indonesia berdasarkan ketentuan yang berlaku pada saat ini adalah untuk mendapatkan perlindungan hukum, maka suatu invensi harus didaftarkan ke Direktorat Jenderal HaKI di dalam Hak Paten menganut sistem first to file file first to protect yang artinya siapa yang mendaftar duluan, maka hak dia yang akan dilindungi. Jika dikaitkan dengan Prospect theory teori mengenai perlindungan paten oleh seharusnya Edijanto mendapat perlindungan hukum atas temuan yang pertama kali ditemukannya tersebut. Namun dalam kenyataannya hak paten yang sudah diberikan oleh Direktorat Jenderal HaKI dapat dibatalkan dan tidak memiliki kekuatan hukum yang jelas Bentuk perlindungan hukum bagi pemegang hak paten di Indonesia berdasarkan UU paten adalah memberikan hak kepada pemilik paten untuk mengajukan pengaduan dan atau gugatan terhadap pihak yang melakukan pelanggaran paten baik pelanggaran pidana dan atau perdata.
\end{abstract}




\section{A. INTRODUCTION}

1. PERLINDUNGAN

HUKUM PATEN OLEH

SETYO PURWANTORO

DIREKTORAT PATEN

DIREKTORAT JENDERAL

HAK KEKAYAAN

INTELEKTUAL

KEMENTERIAN HUKUM

DAN HAM RI 05/20/15 1

2. DEFINISI DAN JENIS

05/20/15 2

3. Paten adalah: Hak eksklusif

yang diberikan oleh Negara kepada

Inventor atas hasil Invensinya di

bidang teknologi, untuk selama

waktu tertentu melaksanakan

sendiri Invensinya tersebut atau

memberikan persetujuannya

kepada pihak lain untuk

melaksanakannya 05/20/15 3

4. JENIS PATEN 1. Paten

(Invention) 2. Paten Sederhana

(Simple Patent, Utility Models).

05/20/15 4

5. PERBEDAAN PATEN N o

Keterangan Paten Paten

Sederhana 1 Jumlah Klaim 1

invensi atau beberapa invensi

yang merupakan satu kesatuan

invensi 1 invensi 2 Masa

Perlindungan 20 thn terhitung sejak tanggal penerimaan permohonan paten 10 thn terhitung sejak tanggal penerimaan 3 Pengumuman Permohonan 18 bulan setelah tanggal penerimaan 3 bulan setelah tanggal penerimaan 4 Jangka Waktu Mengajukan Keberatan 6 bulan terhitung sejak diumumkan 3 bulan terhitung sejak diumumkan 5 Yang diperiksa dalam pemeriksaan substantif Kebaharuan (novelty), langkah inventif \& dapat diterapkan dalam industri Kebaharuan (novelty) \& dapat diterapkan dalam industri 6 Lama Pemeriksaan Substantif 36 bulan terhitung sejak tanggal penerimaan permohonan pemeriksaan substantif 24 bulan terhitung sejak tanggal penerimaan permohonan pemeriksaan substantif 7 Objek Paten Produk dan Proses Produk atau alat 6. PENGERTIAN HAK EKSKLUSIF Hak yang diberikan kepada pemegang Paten Oleh Negara Untuk jangka waktu tertentu 10-20 
tahun Melaksanakan secara komersial Memberikan hak lisensi pada pihak lain Pihak lain tanpa persetujuan pemegang Paten dilarang melaksanakan Paten tersebut05/20/15 6

7. Invensi adalah: Ide inventor yang dituangkan dalam suatu kegiatan pemecahan masalah yang spesifik di bidang teknologi dapat berupa produk atau proses atau penyempurnaan dan pengembangan produk atau proses 05/20/15 7

8. Inventor adalah seorang yang secara sendiri atau beberapa orang yang secara bersama-sama melaksanakan ide yang dituangkan ke dalam kegiatan yang menghasilkan Invensi 05/20/15 8 9. $\varpi$ Paten diberikan untuk Invensi yang baru dan mengandung langkah inventif serta dapat diterapkan dalam industri. $\varpi$ Paten sederhana diberikan untuk invensi berupa produk atau alat yang baru dan mempunyai nilai kegunaan praktis disebabkan bentuk, konfigurasi, konstruksi atau komponen serta dapat diterapkan dalam industri. Syarat Invensi Dapat diberi Perlindungan 05/20/15 9

10. a. Proses atau produk yang pengumuman dan penggunaan atau pelaksanaannya bertentangan dengan perundang-undangan yang berlaku, moralitas agama, ketertiban umum atau kesusilaan; b. Metode pemeriksaan, perawatan, pengobatan dan/atau pembedahan yang diterapkan terhadap manusia dan/atau hewan; c. Teori dan metode di bidang ilmu pengetahuan dan matematika;atau d. i. Semua makhluk hidup, kecuali jasad renik; ii. Proses biologis yang esensial untuk memproduksi tanaman atau hewan, kecuali proses non-biologis atau proses mikrobiologis. Paten tidak diberikan untuk Invensi 05/20/15 10 11. 05/20/15 11 PENGAJUAN PERMOHONAN PATEN • Paten diberikan atas dasar Permohonan • Pengajuan Permohonan Paten dapat dilakukan dengan 3 cara, yaitu: a. Secara langsung ke Direktorat Jenderal HKI; b. Melalui kuasa, dalam hal ini konsultan HKI ; c. Melalui Kantor Wilayah Kementerian Hukum dan HAM di seluruh Indonesia.

12. 05/20/15 $12 \neg$ Invensi yang didaftarkan Paten haruslah merupakan satu invensi atau beberapa invensi yang merupakan satu kesatuan invensi. $\neg$ Pendaftaran Paten merupakan first to file. 13. PENSIL + PENGHAPUS PATEN BARU 1. Pensil 2. Penghapus 1. Pensil + Penghapus 14. TUSUK GIGI - PATEN SEDERHANA

15. POST IT

16. CONTOH PATEN 17. PEMBUKA BOTOL 18. PROSES DAN TIME LINE 05/20/15 18 19. Jump to first page PROSES UNTUK MENDAPATKAN PATEN PEMOHON LOKET 
PENERIMAAN

DIREKTORAT PATEN

PEMERIKSAAN FORMAL

PUBLIKASIA

PEMERIKSAAN

SUBSTANTIF PUBLIKASI B

DIBERI DITOLAK

KEPUTUSAN DIBERI

DITOLAK APLIKASI

KOMISI BANDING

20. Time Line Permohonan Paten

Maks. 18 bulan 6 bulan Maks. 36

bulan Masa Pemeriksaan

Substantif Masa Publikasi Filling

Date Keputusan total prosedur +

72 bulan Publication of Patent

Application Publication of

Granted/ Issued Patent Maks 36

bulan jangka waktu permohonan

pemeriksaan substantif

Pemeriksaan Formalitas (Masa

Tunggu)

21. Time Line Permohonan

Paten Sederhana Maks. 3 bulan

3 bulan Maks. 18 bulan Masa

Pemeriksaan Substantif Masa

Publikasi Filling Date

Pemeriksaan Formalitas (Masa

Tunggu) Keputusan total

prosedur +24 bulan

Publication of Simple Patent

Application Publication of

Granted/Issued Patent

22. SUBYEK DAN JANGKA

WAKTU PERLINDUNGAN

05/20/15 22

23. 05/20/15 23 Yang berhak

memperoleh Paten adalah

Inventor atau yang menerima

lebih lanjut hak Inventor yang

bersangkutan. Jika suatu

Invensi dihasilkan oleh

beberapa orang secara

bersama-sama, hak atas Invensi

tersebut dimiliki secara bersama-sama oleh para

inventor yang bersangkutan

SUBJEK PATEN

24. 05/20/15 24 o Dalam

hubungan kerja, pihak yang

memberikan pekerjaan adalah

pihak yang berhak memperoleh

Paten, kecuali diperjanjikan

lain o Karyawan maupun

pekerja yang menggunakan

data dan/atau sarana yang

tersedia dalam pekerjaan, maka

kantor tempat karyawan

tersebut bekerja yang berhak

memperoleh Paten

25. 05/20/15 25 Paten 20 Tahun

terhitung sejak Tanggal

Penerimaan. Paten Sederhana 10

Tahun terhitung sejak Tanggal

Penerimaan Catatan: Perlindungan

hukum Paten dalam lingkup

regional, walau kebaruan lingkup

universal. Kedua jenis Paten diatas

tidak dapat diperpanjang untuk jangka waktu perlindungannya.

JANGKA WAKTU

PERLINDUNGAN

26. HAK DAN KEWAJIBAN

$05 / 20 / 1526$

27. 05/20/15 27 Hak Pemegang

Paten Secara Ekonomi :

Pemegang Paten mempunyai

Hak Eksklusif untuk

melaksanakan Paten yang

dimilikinya danmelarang pihak

lain yang tanpa persetujuannya

: membuat, menggunakan,

menjual, mengimpor,

menyewakan, menyerahkan,

atau diserahkan produk Paten

yang dimilikinya (Pasal 16 UU

No. 14 th 2001). Secara Moral :

Suatu hak yang lahir dari asas

pengakuan dalam bentuk

Sertifikat Paten yang untuk 
tetap mencantumkan nama Inventornya. Dikecualikan dari ketentuan tersebut apabila pemakaian Paten tersebut untuk kepentingan pendidikan, penelitian, percobaan, atau analisis sepanjang tidak merugikan kepentingan yang wajar dari Pemegang Paten. 28. 05/20/15 28 1. Membuat produk atau menggunakan proses yang diberi Paten di Indonesia kecuali hanya layak dilakukan secara regional. 2. Membayar biaya tahunan. Kewajiban Pemegang Paten: 29. 05/20/15 29 SERTIFIKAT PATEN MERUPAKAN BUKTI HAK ATAS PATEN. 30. KOMISI BANDING PATEN 05/20/15 30

31. Komisi Banding Paten Adalah Badan Khusus Yang Independen Dan Berada Di Lingkungan Kementerian Yang Membidangi Hak Kekayaan Intelektual 05/20/15 31 32. 05/20/15 32 wPermohonan banding dapat diajukan terhadap penolakan permohonan yang berkaitan dengan alasan dan dasar pertimbangan mengenai hal-hal yang bersifat substantif dan diajukan paling lama 3 (tiga) bulan terhitung sejak tanggal pengiriman surat pemberitahuan penolakan permohonan $\varpi D a l a m$ hal komisi banding menolak permohonan banding, pemohon atau kuasanya dapat mengajukan gugatan atas keputusan tersebut ke pengadilan niaga dalam waktu paling lama 3 (tiga) bulan terhitung sejak tanggal diterimanya keputusan penolakan tersebut 33. LISENSI DAN LISENSI WAJIB 33

34. Lisensi adalah izin yang diberikan oleh Pemegang Paten kepada pihak lain berdasarkan perjanjian pemberian hak untuk menikmati manfaat ekonomi dari suatu Paten yang diberi perlindungan dalam jangka waktu dan syarat tertentu. 34

35. Lisensi-wajib adalah

Lisensi untuk melaksanakan

Paten yang diberikan berdasarkan keputusan

Direktorat Jenderal atas dasar permohonan 35

36. Setiap pihak dapat mengajukan permohonan lisensi-wajib kepada Direktorat Jenderal untuk melaksanakan Paten yang bersangkutan setelah lewat jangka waktu 36 (tiga puluh enam) bulan terhitung sejak tanggal pemberian Paten dengan membayar biaya dengan alasan: 1.bahwa Paten yang bersangkutan tidak dilaksanakan atau dilaksanakan tidak sepenuhnya di Indonesia oleh Pemegang Paten atau 2.bahwa Paten telah dilaksanakan oleh Pemegang Paten atau Penerima Lisensi dalam bentuk dan dengan cara yang merugikan kepentingan masyarakat. 36 37. PELAKSANAAN PATEN OLEH PEMERINTAH 37 
38. $\neg$ Pihak-pihak Yang Dapat

Meminta Pelaksanaan Paten Oleh

Pemerintah Adalah Pemerintah

(Kementerian/Lembaga) Terkait $\neg$ Pemerintah Dapat Melaksanakan

Sendiri Paten Yang Bersangkutan

Dalam Hal Pemerintah

Berpendapat Suatu Paten Di Indonesia Sangat Penting Artinya Bagi: a. Pertahanan Keamanan Negara; Atau b. Kebutuhan Yang Sangat Mendesak Untuk Kepentingan Masyarakat. Pelaksanaan Paten oleh Pemerintah dilakukan dengan pemberian imbalan yang wajar kepada Pemegang Paten 38

39. PENGALIHAN PATEN 05/20/15 39

40. Pengalihan Paten dapat terjadi karena: 1.Pewarisan; 2.Hibah; 3.Wasiat; 4.Perjanjian Tertulis; atau 5.Sebab lain yang dibenarkan oleh peraturan perundangundangan. 41. Pengalihan paten harus didaftarkan ke direktorat jenderal. Jika tidak didaftar makapengalihan paten tersebut dapat dinyatakan batal demi hukum 05/20/15 41 42. BIAYA TAHUNAN 05/20/15 42

43. 1) Pembayaran biaya tahunan untuk pertama kali harus dilakukan paling lambat setahun terhitung sejak tanggal pemberian Paten. 2) Untuk pembayaran tahun-tahun berikutnya, selama Paten itu berlaku harus dilakukan paling lambat pada tanggal yang sama dengan tanggal pemberian Paten atau pencatatan Lisensi yang bersangkutan. 3)
Pembayaran biaya tahunan sebagaimana dimaksud pada angka (1) dihitung sejak tahun pertama Permohonan. 43 44. PEMBATALAN PATEN 05/20/15 44 45. o BATAL DEMI HUKUM o BATAL ATAS PERMOHONAN PEMEGANG PATEN o BATAL BERDASARKAN GUGATAN KE PENGADILAN NIAGA 45 46. BATAL DEMI HUKUM Paten dinyatakan batal demi hukum apabila Pemegang Paten tidak memenuhi kewajiban membayar biaya tahunan dalam jangka waktu yang ditentukan dalam Undang-undang ini, yaitu 3 (tiga) tahun berturut-turut. 46 47. BATAL ATAS PERMOHONAN PEMEGANG PATEN Paten dapat dibatalkan oleh Direktorat Jenderal untuk seluruh atau sebagian atas permohonan Pemegang Paten yang diajukan secara tertulis kepada Direktorat Jenderal 47 48. BATAL ATAS GUGATAN PENGADILAN • Gugatan pembatalan dapat diajukan oleh pihak ketiga kepada Pemegang Paten melalui Pengadilan Niaga. • Jika gugatan pembatalan Paten hanya mengenai satu atau beberapa klaim atau bagian dari klaim, pembatalan dilakukan hanya terhadap klaim yang pembatalannya digugat 48 
49. JENIS DELIK DAN SANKSI

PIDANA 05/20/15 49

50. JENIS DELIK Tindak Pidana

Paten merupakan delik aduan

51. SANKSI PIDANA Barang

siapa dengan sengaja dan tanpa

hak melanggar hak Pemegang

Paten dipidana dengan pidana

penjara paling lama 4 (empat)

tahun dan/atau denda paling

banyak Rp 500.000.000,00 (lima

ratus juta rupiah). Barang siapa

dengan sengaja dan tanpa hak melanggar hak Pemegang Paten

Sederhana dipidana dengan pidana

penjara paling lama 2 (dua) tahun dan/atau denda paling banyak Rp

250.000.000,00 (dua ratus lima

puluh juta rupiah). 51

52. DIKECUALIKAN DARI

KETENTUAN PIDANA

๘Mengimpor suatu produk farmasi

yang dilindungi Paten di Indonesia,

yang produk tersebut telah

dimasukkan ke pasar di suatu

negara oleh Pemegang Paten yang

sah dengan syarat produk itu

diimpor sesuai dengan ketentuan

perundang- undangan yang

berlaku. ๗Memproduksi produk

farmasi yang dilindungi Paten di

Indonesia dalam jangka waktu 2

(dua) tahun sebelum berakhirnya

perlindungan Paten dengan tujuan

untuk proses perizinan kemudian

melakukan pemasaran setelah

perlindungan Paten tersebut

berakhir. 52

53. 05/20/15 53

54. INOVASI MULAI

SEKARANG!

55. TERIMA KASIH 05/20/15 55

www.dgip.go.id

\section{B. CONTENT}

Perkembangan ilmu pengetahuan dan teknologi dimanapun tidak dapat dilepaskan dari peran perguruan tinggi sebagai sumber utama invensi dari hasil-hasil penelitian secara berkesinambungan. Perlindungan hukum atas invensi-invensi melalui regim perlindungan paten merupakan langkah yang sangat strategis bagi pemanfataan invensi lebih lanjut dalam kegiatan perdagangan.

Pertama, keberadaan sistem paten, yang memungkinkan inventor mendapatkan hak eksklusif untuk melaksanakan invensinya pada waktu yang terbatas atau mengalihkan pada orang lain, memberikan landasan yang kuat bagi peneliti untuk melakukan penelitian dan pengembangan, karena adanya jaminan perlindungan hukum bagi invensinya dalam pemanfaatan selanjutnya sehingga peneliti juga bisa mendapatkan keuntungan ekonomis.

Kedua, Periode yang terbatas bagi pemegang hak paten untuk menggunakan invensi tersebut memberikan kesempatan bagi investor untuk mendapatkan pengembalian atas modal yang telah ditanamkan serta memberikan perlindungan atas persaingan usaha yang tidak jujur. Ketiga, keberadaan sistem paten yang baik merupakan sumber informasi yang berharga bagi pengembangan, pengklasifikasian dan penyebarluasan teknologi bagi semua orang, terutama para peneliti agar tidak melakukan 
penelitian yang sudah pernah

dilakukan dan hasilnya sudah

dipatenkan oleh pihak lain (re-

inventing wheel). Hal ini

dimungkinkan, karena penerima paten

juga diharuskan menguraikan

invensinya secara lengkap, sehingga

pada saat berakhirnya paten, informasi

tersebut menjadi public domain yang

bisa diakses siapa saja.

Terminologi paten berasal dari bahasa latin "littera patents" yang berarti terbuka atau bebas.[5] Paten Venesia merupakan aturan hukum tertulis pertama yang memuat konsep dasar perlindungan paten misalnya memberikan hak istimewa bagi inventor untuk memonopoli invensinya selama 10 tahun.[6] Dalam perkembangan selanjutnya prinsip dasar ini tetap berlaku dengan berbagai variannya, sampai pada aturan terbaru dalam TRIPs yang berlaku seragam untuk semua anggota WTO. Berlakunya TRIPs membawa perubahan yang cukup signifikan bagi sistem paten di Indonesia, karena Indonesia juga harus menyesuaikan pranata hukumnya. Ada 4 hal yang harus dipenuhi dalam pranata hukum paten di Indonesia sejalan dengan berlakunya TRIPs:

1. Perluasan obyek paten untuk semua invensi baik berupa proses atau produk di semua bidang ilmu pengetahuan.(ps.27(1) TRIPs).

2. Pengakuan paten atas varitas baru tanaman (ps.27(2) TRIPs).

3. Jangka waktu perlindungan paten selama 20 tahun dan tidak ada perpanjangan (ps.33 TRIPs).
4. Berlakunya Azas pembuktian terbalik (reverse burden of proof) dalam pelanggaran paten.(ps 34 TRIPs).

Pasal 1 angka 1 UU 14/2001 menyatakan :

Paten adalah hak eksklusif yang diberikan oleh Negara kepada inventor atas hasil invensinya di bidang teknologi, yang untuk selama waktu tertentu melaksanakan sendiri hasil penemuannya tersebut atau memberikan persetujuannya kepada pihak lain untuk melaksanakannya.

Dari definisi tersebut diatas ada beberapa hal yang penting untuk diperhatikan:

Pertama, paten pada hakekatnya adalah perjanjian antara negara (sebagai pemberi paten) dengan Inventor (sebagai penerima paten). Sebagai suatu perjanjian maka ada hak dan kewajiban yang harus dipatuhi, dalam hal paten negara memberikan hak kepada inventor untuk memanfaatkan invensinya secara eksklusif (monopoli), akan tetapi negara juga mewajibkan inventor untuk mengungkapkan invensinya secara rinci.

Kedua, Lingkup paten, Pemberian hak paten harus memenuhi 3 syarat (pasal 2 UU 14/2001) yaitu:

1. Unsur kebaruan (Novelty)

Suatu invensi dianggap baru, jika invensi tersebut tidak diantisipasi 
dalam "prior ar"t $t$ [7]. Penetapan "prior art" biasanya didasarkan pada adanya perbedaan antara publikasi yang dicetak atau pengungkapan lisan atau pemakaian sebelumnya.

1. Mengandung langkah inventif (non-obviousness), artinya suatu invensi mengandung langkah inventif apabila bagi seseorang yang mempunyai keahlian tertentu di bidang teknik merupakan hal yang tidak dapat diduga sebelumnya. Untuk melihat apakah suatuinvensi mengandung langkah inventif didasarkan pada dua hal yaitu:pertama, merupakan hasil pemikiran yang kreatif, kedua, adanya kemajuan yang bermakna dari teknologi yang terdahulu.

3. Dapat diterapkan dalam industri (industrial Applicable), invensi tersebut tidak hanya berupa teori, akan tetapi merupakan suatu proses atau produk yang dapat diaplikasikan dalam bidang manufaktur untuk menghasilkan barang secara massal.

Ketiga, jangka waktu perlindungan paten adalah 20 tahun untuk paten biasa/standart patent ( ps.8 UU 14/2001) dan 10 tahun untuk paten sederhana/petty patent (ps. $9 \mathrm{UU}$ 14/2001).Rasio dari penetapan jangka waktu perlindungan bahwa dalam rentang waktu tersebut diatas inventor dan investor dianggap telah mendapatkan kembali biaya yang telah dikeluarkan untuk meneliti dan mengembangkan paten.

Keempat, Subyek paten adalah orang yang berhak memperoleh paten yaitu inventor atau beberapa inventor (untuk invensi yang dihasilkan bersamasama).(ps.10 UU 14/2001).

Kelima, Hak pemegang paten(16 UU 14/2001), undang-undang memberikan hak bagi pemegang hak paten untuk melaksanakan patennya dan melarang pihak lain yg tanpa persetujuannya :

1. Dalam hal paten produk: membuat, menggunakan, menjual, mengimpor, menyewakan, menyerahkan atau menyediakan untuk dijual atau disewakan atau diserahkan produk yang diberi paten;

2. Dalam hal paten proses; menggunakan produksi yang diberi paten untuk membuat barang dan tindakan lainnya sebagaimana dimaksud dalam huruf a.

Keenam,Kewajiban pemegang paten adalah melaksanakan patennya di Indonesia, bila berupa paten produk maka wajib membuat produknya di Indonesia, bila berupa paten proses maka wajib menggunakan proses yang diberi paten di Indonesia. (ps.17 UU 14/2001). Rasio ketentuan dalam poin kelima dan keenam adalah dengan pemberian paten diharapkan juga bisa terjadi alih teknologi, penyerapan investasi dan penyediaan lapangan pekerjaan sehingga secara simultan pemberian paten dapat menggerakan kegiatan perekonomian.

Ketujuh, paten diberikan atas dasar permohonan (stelsel konstitutif), karena dalam penentuan ada tahapantahapan yang harus dipenuhi sebelum permohonan paten dikabulkan.

Kedelapan, Penyelesaian sengketa, apabila ada pelanggaran paten, undang-undang menawarkan tiga cara 
untuk menegakan hak yaitu melalui gugatan perdata (ps. 117 s/d123), melalui Alternatif Penyelesaian Sengketa ( ps. 124) serta tuntutan pidana ( ps.130-133), satu hal yang harus diingat bahwa sistem pembuktian yang dipakai adalah sistem pembuktian terbalik (ps 119) hal ini berkaitan dengan sulitnya pembuktian pelanggaran paten dan untuk menjaga kepentingan yang wajar dari pemegang hak paten.

\section{DISCUSSION}

3. Aspek Perlindungan Hukum HKI untuk Hasil Penelitian di Perguruan Tinggi

Ada beberapa persoalan mendasar berkaitan dengan perlindungan HKI atas Hasil penelitian di Perguruan Tinggi.

Pertama, siapakah yang paling berhak untuk mendapatkan Hak kekayaan intelektual? untuk menjawab pertanyaan ini , kita harus menelusuri kembali proses dari penelitian yang bersangkutan, karena ada berbagai kemungkinan yang bisa terjadi:

1. Bila penelitian dilakukan oleh peneliti dengan kapasitas sebagai dosen Universitas, dibiayai oleh universitas, dilakukan dalam jam kerja dan menggunakan fasilitas milik universitas, maka menurut undang-undang pemilik HKI adalah Universitas, karena universitas dapat disetarakan sebagai majikan.
2. Bila penelitian dilakukan oleh peneliti dengan sumber pendanaan dari luar universitas, maka pemilik HKI adalah pihak yang mendanai penelitian tersebut, peneliti hanya berhak disebut namanya sebagai inventor atau pencipta, pemberi dana dapat disetarakan dengan pemesan.

3. Bila penelitian dilakukan oleh peneliti dengan sumber pendanaan dari luar universitas, akan tetapi menggunakan fasilitas universitas maka pemilik HKI adalah pemberi dana dan Universitas.

4. Bila penelitian dilakukan dan dibiayai sendiri oleh peneliti, akan tetapi menggunakan fasilitas universitas maka pemilik HKI adalah peneliti dan universitas.

5. Bila penelitian dilakukan dan dibiayai sendiri oleh peneliti, maka pemilik HKI adalah peneliti.

Persoalan kepemilikan HKI dalam konteks hubungan kerja dianut prinsip bahwa majikan/ pemesan yang menjadi pemilik HKI ( ps.12 UU 14/2001 dan ps 8 UU 19/2002).

Ketentuan tersebut diatas bukanlah harga mati, karena untuk menentukan kepemilikan HKI para pihak yang bekerja sama dapat membuat kesepakatan-kesepakan tentang kepemilikan HKI dari hasil penelitian, apalagi bila dilihat bahwa kedudukan antara dosen dan universitas tidaklah persis sama seperti dalam hubungan majikan dan karyawan dalam suatu perusahaan, sehingga penentuan kepemilikan hasil penelitian bukanlah hal yang mudah.

Sebagai bandingan, di Australia sejak tahun 1995 terbentuk komite yang 
terdiri dari para wakil rektor seUniversitas di Australia yang duduk bersama untuk menetapkan pedoman dasar kepemilikan HKI untuk hasil penelitian di Universitas, walaupun pelaksanaan selanjutnya diserahkan pada kebijakan masing-masing universitas. [14] Pada umumnya penentuan kepemilikan disandarkan pada asumsi hukum secara umum dan dibedakan menurut obyek HKI-nya misalnya[15]:

a. Hasil penelitian yang dihasilkan oleh dosen dalam kaitan dengan pekerjaannya dan terikat perjanjian kerja dengan universitas, biasanya universitas adalah pemilik HKI kecuali diperjanjikan lain dengan tidak mengesampingkan kepentingan peneliti misalnya:

- Adanya pembagian keuntungan yang seimbang (fair share) bila karya tersebut dikomersialisasikan;

- Adanya jaminan yang layak atas keutuhan karya (hasil penelitian);

- Adanya pengakuan sebagai inventor atau pencipta.

b. Hasil penelitian yang dihasilkan dengan menggunakan fasilitas (laboratorium, computer, media lainnya maka pemilik HKI adalah Universitas.

c. Bila hasil penelitian tersebut berbasis pada hasil penelitian terdahulu milik universitas (baik yang dipatenkan atau tidak) maka pemilik HKI adalah Universitas.

d. Bila penelitian itu melibatkan beberapa dosen, karyawan dan mahasiswa maka pemilik HKI adalah Universitas.

e. Bila penelitian didanai oleh Universitas secara langsung maka pemilik HKI adalah Universitas, kecuali diperjanjikan lain.

Kedua, Bagaimanakah bentuk perlindungan hukumnya? Untuk menjawab persoalan ini maka harus dicermati dulu dalam bentuk apa hasil penelitian itu sendiri. Bila yang dimaksud adalah laporan penelitian (karya tulis), maka bentuk perlindungan HKI mengikuti regime hak cipta. Bila yang di maksud adalah teknologi maka dapat dipilah-pilah menurut obyek HKI, misalnya bila hasil penelitian tersebut merupakan teknologi ( baik proses maupun produk) maka bentuk perlindungan hukumnya mengikuti paten, paten sederhana atau rahasia dagang. Bila hasil penelitian berupa bentuk dua dimensi atau tiga dimensi yang lebih ditekankan pada penampakan luar maka bentuk perlindungannya mengikuti desain.

Ketiga, strategi perencanaan untuk mendapatkan HKI atas hasil penelitian. Persoalan ini akan muncul apabila hasil penelitian tersebut merupakan invensi yang mungkin dapat didaftarkan HKI-nya. Misalnya, Hasil penelitian yang berupa teknologi yang layak dipatenkan. Hal-hal yang harus diperhatikan oleh peneliti adalah persoalan cara, tempat dan waktu pengungkapan invensi atas penelitian dengan tanggal diajukannya 
permohonan paten, karena bila tidak cermat akan dapat menggugurkan unsur kebaruan (novelty) dari invensi hasil penelitian tersebut.

Ada tiga cara yang dianggap sebagai pengungkapan invensi yang bisa dianggap sebagai bagian prior art sebagai berikut [16]:

- Penguraian invensi melalui tulisan secara rinci yang diterbitkan atau dipublikasikan;

- Penguraian invensi secara lisan yang diungkapkan di muka umum;

- Pengungkapan melalui pemakaian di muka umum, sehingga setiap orang mampu memakainya.

\section{REFERENCE}

[1] O. M. Febriani and A. S. Putra, "Sistem Informasi Monitoring Inventori Barang Pada Balai Riset Standardisasi Industri Bandar Lampung," J. Inform., vol. 13, no. 1, pp. 90-98, 2014.

[2] A. S. Putra, "Paperplain: Execution Fundamental Create Application With Borland Delphi 7.0 University Of Mitra Indonesia," 2018.

[3] A. S. Putra, "2018 Artikel Struktur Data, Audit Dan Jaringan Komputer," 2018.

[4] A. S. Putra, "ALIAS MANAGER USED IN DATABASE DESKTOP STUDI CASE DB DEMOS."

[5] A. S. Putra, "COMPREHENSIVE SET OF PROFESSIONAL FOR DISTRIBUTE COMPUTING."

[6] A. S. Putra, "DATA
ORIENTED RECOGNITION IN BORLAND DELPHI 7.0."

[7] A. S. Putra, "EMBARCADERO DELPHI XE 2 IN GPUPOWERED FIREMONKEY APPLICATION."

[8] A. S. Putra, "HAK ATAS KEKAYAAN INTELEKTUAL DALAM DUNIA TEKNOLOGY BERBASIS REVOLUSI INDUSTRI 4.0."

[9] A. S. Putra, "IMPLEMENTASI PERATURAN

PERUNDANGAN UU. NO 31 TAHUN 2000 TENTANG DESAIN INDUSTRI BERBASIS INFORMATION TECHNOLOGY."

[10] A. S. Putra, "IMPLEMENTATION OF PARADOX DBASE."

[11] A. S. Putra, "IMPLEMENTATION OF TRADE SECRET CASE STUDY SAMSUNG MOBILE PHONE."

[12] A. S. Putra, "IMPLEMENTATION

PATENT FOR APPLICATION WEB BASED CASE STUDI WWW. PUBLIKLAMPUNG. COM."

[13] A. S. Putra, "IMPLEMENTATION SYSTEM FIRST TO INVENT IN DIGITALLY INDUSTRY."

[14] A. S. Putra, "MANUAL REPORT \& INTEGRATED DEVELOPMENT

ENVIRONMENT BORLAND DELPHI 7.0."

[15] A. S. Putra, "PATENT AS RELEVAN SUPPORT RESEARCH."

[16] A. S. Putra, "PATENT FOR 
RESEARCH STUDY CASE OF APPLE. Inc."

[17] A. S. Putra, "PATENT PROTECTION FOR APPLICATION INVENT."

[18] A. S. Putra, "QUICK REPORT IN PROPERTY PROGRAMMING."

[19] A. S. Putra, "REVIEW CIRCUIT LAYOUT COMPONENT

REQUIREMENT ON ASUS NOTEBOOK."

[20] A. S. Putra, "REVIEW TRADEMARK PATENT FOR INDUSTRIAL TECHNOLOGY BASED 4.0."

[21] A. S. Putra, "TOOLBAR COMPONENT PALLETTE IN OBJECT ORIENTED PROGRAMMING."

[22] A. S. Putra, "WORKING DIRECTORY SET FOR PARADOX 7."

[23] A. S. Putra, "ZQUERY CONNECTION IMPLEMENTED

PROGRAMMING STUDI CASE PT. BANK BCA Tbk."

[24] A. S. Putra, D. R. Aryanti, and I. Hartati, "Metode SAW (Simple Additive Weighting) sebagai Sistem Pendukung Keputusan Guru Berprestasi (Studi Kasus: SMK Global Surya)," in Prosiding Seminar Nasional Darmajaya, 2018, vol. 1, no. 1, pp. 85-97.

[25] A. S. Putra and O. M. Febriani, "Knowledge Management Online Application in PDAM Lampung Province," in Prosiding International conference on Information Technology and Business
(ICITB), 2018, pp. 181-187.

[26] A. S. Putra, O. M. Febriani, and B. Bachry, "Implementasi Genetic Fuzzy System Untuk Mengidentifikasi Hasil Curian Kendaraan Bermotor Di Polda Lampung," SIMADA (Jurnal Sist. Inf. dan Manaj. Basis Data), vol. 1, no. 1, pp. 21-30, 2018.

[27] A. S. Putra, H. Sukri, and K. Zuhri, "Sistem Monitoring Realtime Jaringan Irigasi Desa (JIDES) Dengan Konsep Jaringan Sensor Nirkabel," IJEIS (Indonesian J. Electron. Instrum. Syst., vol. 8, no. 2, pp. 221-232.

[28] D. P. Sari, O. M. Febriani, and A. S. Putra, "Perancangan Sistem Informasi SDM Berprestasi pada SD Global Surya," in Prosiding Seminar Nasional Darmajaya, 2018, vol. 1, no. 1, pp. 289-294. 